\title{
Progressive Succession at Vegetation of Gölardı (Terme/ Samsun) Natural Protected Area
}

\section{Gölardı (Terme/Samsun) Tabiatı Koruma Alanı Vejetasyonunda Progressif Süksesyon}

\author{
Research Article \\ Hasan Korkmaz ${ }^{*}$, Cebrail Yıldırım² \\ 'Ondokuzmayıs University, Arts-Sciences Faculty, Biology Department, Atakum, Samsun, Turkey. \\ ${ }^{2}$ Ministry of National Education, Atakum Cumhuriyet Anatolian College, Atakum, Samsun, Turkey.
}

\section{A B S T R ACT}

n this study, it was determined that the progressive succession in Gölardı Natural Protected Area, (Terme/ Samsun) which is in the eastern part of Yeşilırmak delta plain, basically developed in hydroseral and psammoseral processes and that it consisted of plant communities, six of which belonged to hydroseral succession main stages and three of which belonged to psammoseral successional main stages.

\section{Key Words}

Vegetation, succession, Gölardı, Terme.

\section{ÖZET}

u çalışma ile, Yeşilırmak Delta ovasının doğu kısmını oluşturan, Gölardı (Terme/Samsun) Tabiatı Koruma Alanı'nındaki progressif süksesyonun, temel olarak hidroseral ve psammoseral süreçler halinde geliştiği ve hidroseral süksesyonun 6 , psammoseral süksesyonun ise 3 ana basamak halinde biraraya gelmiş bitki topluluklarından oluştuğu belirlenmiştir.

\section{Anahtar Kelimeler}

Vejetasyon, süksesyon, Gölardı, Terme.

Article History: Received: Jun 22, 2015; Revised: Dec 12, 2015; Accepted: Mar 20, 2016; Available Online: Apr 1, 2016.

DOI: $10.15671 /$ HJBC.20164417663

Correspondence to: H. Korkmaz; Ondokuz Mayıs University, Faculty of Science and Arts, Department of Biology, Samsun, Turkey. 


\section{INTRODUCTION}

The key factor of vegetation which has a dynamic structure is succession [1]. For this reason, all changing processes in vegetation should be dealt with from successional perspective. However, the conditions of the habitat, where the interactions such as establishment, competition, reaction, allelopaty, etc., occur during successional processes, determine the process of succession and the structure of climax vegetation which occur in the habitat. Because these dynamic process lead to changes in the presence and abundance values of the plant species in community by time.

Thus, searching for the dynamics and factors of the successional process in a region provide us with knowledge about the past and future of the vegetation in the region. A traditional view of succession is that assemblages slowly and progressively occupy a site until a homogeneous, sustainable community develops [2]. Bazzaz [3] regards succession as the main concept of ecology, and defines it as the spread and permanent establishment of populations of species in any area. Based on the above mentioned knowledge, it is possible to define succession as dynamic and staged process during which a plant community is replaced by a completely different community as a result of some changes in its autogenic (floristic biodiversty, structure, life form, etc.) and allogenic properties (soil nutrient, productivite, other abiotic factors, etc.) that ocur by time.

As river deltaic plains [4], riparian floodplains [5], salt marshes [6] freshwater marshes [7], coastal or inland sand dunes [8,9], volcanic erupted areas [10] and deglaciation areas (edge of retreating glacier; glacier forelands) [11] are offer an excellent opportunity to study processes of primary succession. However deltaic plains of big rivers belong to the most variable and least predictable environments on earth. River deltaic plains are unstable areas which are suitable for primer progressive succession studies because of the fact that the habitats have been newly formed and that plant establishments have just started (in those places).

In this study, we tried to determine progressive successional processes in the vegetation of Gölardı
(Terme/Samsun) Natural Protected Area, which was first declared as "natural protected area" by the Ministry of Environment and Forestry in 1975 and then declared as "wildlife development area" in 2005 [12]. The area was preferred owing to the fact that objective data could be collected about primer progressive successional process since it is a deltaic plain under special protection.

\section{Study Area}

Gölardı Natural Protected Area, located in the eastern part of the Yeşilırmak Delta Plain $\left(41^{\circ} 12^{\prime} 47^{\prime \prime}-41^{\circ} 20^{\prime} 32^{\prime} \mathrm{N}\right.$; 36 $\left.46^{\circ} 49^{\prime} 18^{\prime \prime}-37^{\circ} 01^{\prime} 19^{\prime \prime} \mathrm{E}\right)$ is Quaternarian alluvial delta plain made up of the materials carried by the Stream Terme $[13,14]$. It is an area of 3306.1 ha in total, most of which is covered with hydromorphic alluvial soils, and the part which borders the Black Sea is made up of costal sand dunes with an average width of 50 m (Figure 1). In this study area there are many drainage canals and canalets, and Simenit Lagoon and Akgöl Lake, connected with a canal, which are supplied by ground water. The study area, a mostly deltaic plain, has an average altitude of 4-5 $\mathrm{m}$, and it is exposed to local flooding in some parts between November and May.

Average annual rainfall in Terme is 922.1 $\mathrm{mm}$, and the type of rainfall regime is Au.Wi. Su.Sp. which belongs to marine type I of East Black Sea Oceanic rainfall regime [15]. Average annual temperature is $14.4^{\circ} \mathrm{C}$ at Çarşamba meteorological station, the nearest place to the sudy area where the temperature and rainfall are measured. According to data from this station, the study area is under the influence of rainy and cool-Mediterranean Climate [16]. According to rainfall formula by Erinç [17] Im value is 42.8 and $S$ value is 4.4 , and they are under the influence of wet-climate and submediterranean climate respectivelly. The study area gets sufficient rain every seasons, so no arid period is experienced in the area.

\section{MATERIALS AND METHODS}

All the main stages and substages of primer progressive succession in Gölardı (Terme/ Samsun) Wildlife Development Area have been studied on permanent samples determined 


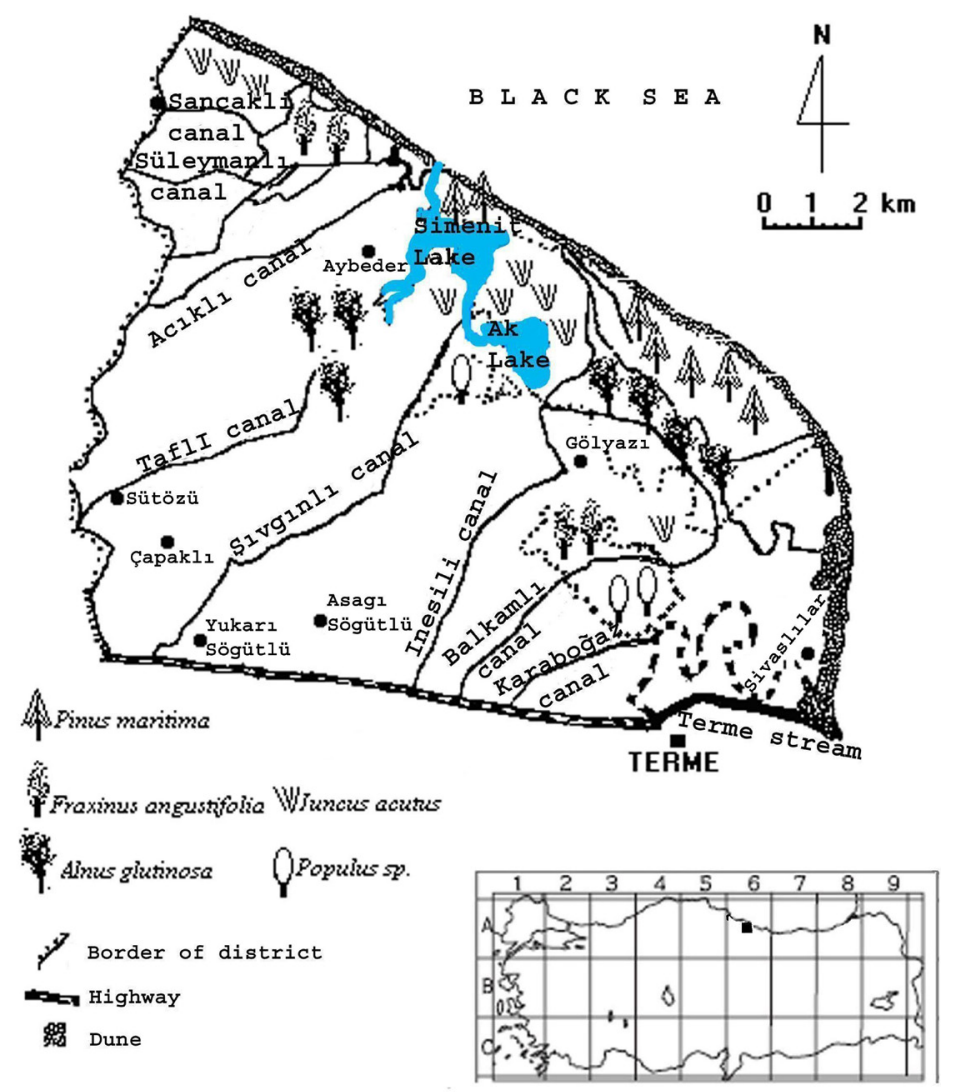

Figure 1. Map of the study area.

according to Braun- Blanquet method [18]. For this reason, ten permanent plot samples were determined according to minimal area concept [19] in the homogenous places of each community which represent successional stages, and floristic data were recorded on weekly basis between February-November. After vascular plant samples in plot samples were identified according to Flora of Turkey [20-22], they were revised refering to Güner et al. [23].

\section{RESULTS}

Primer progressive succession basically developes in two successional processes, one of which is psammoseral in coastal sand dunes and the other is hydroseral in the areas begining from coasts of lakes which get flooded in different periods. The stages related to both successional process that take place in the study area, and the communities that represent them are as follows:

\section{Hydroseral Succession}

Periodical floodings and drawdowns occur around Akgöl and Simenit lakes and in some other parts of the study area. As this causes graidents in soil water table levels and soil moisture depending on the period of flooding and drawdown, it functions as a factor that effect progressive successional stages directly. It was determined that progressive hydroseral succession consisted of 6 major and 11 intemediate stages (Table 1, Figure 2). While the first two stages are comprised of aquatic communities, the third major stage is made up aquatic and amphibic communities, the fourth and fifth major stages are made up of flooded communities and the sixth major stage had only terrestrial community.

\section{Free Floating Stage}

Hydroseral progressive succession in the study area starts with free floating plant species. They grow at 4-5 meters depts of Akgöl an Simenit lakes in average and constitute local and dense communities. Species diversity of pioneer 
Table 1. Hydroseral successional stages.

\begin{tabular}{lc}
\hline Major Successional Stages & Intermediate Successional Stages and Communities \\
\hline 1-Free Floating Stage & \multicolumn{1}{c}{ Lemna gibba, L. minor community } \\
\hline 2-Submerged Stage & $\begin{array}{r}\text { Ceratophyllum demersum, C. submersum, Myrophyllum spicatum and } \\
\text { Polygonatum pectinatus mixed community }\end{array}$ \\
\cline { 2 - 2 } & a-Nymphaea alba community \\
\cline { 2 - 2 } 3-Marshy Stage & b-Typha angustifolia community \\
\cline { 2 - 2 } & c-Phragmites australis community \\
\hline 4-Meadow Stage & d-Cladium mariscus community \\
\hline 5-Flooded Forest Stage & e-Sparganium erectum subsp. neglectum community \\
\hline 6-Climax Forest Stage & a-Juncus acutus community \\
\hline
\end{tabular}

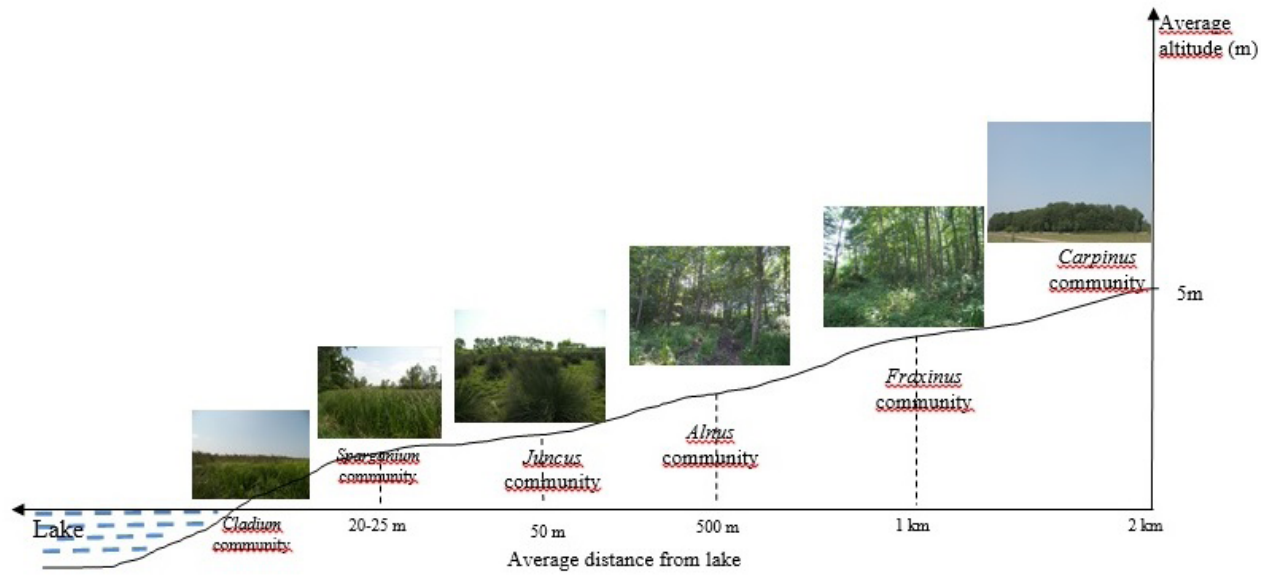

Figure 2. Stages of hydroseral succession.

communities of the begining stage of hydroseral succession is quite few in number, and the widespread species are Lemna gibba and L. minor.

\section{Submerged Stage}

Hydroseral succession communities at this stage consist of aquatic plant species which are in submerged position and rooted in the bottom mud with their roots and rhisomes. They grow at 2-3 m depths of Akgöl and Simenit lakes and some deep drainage canals and canalets. There's more plant diversity at this stage compared to free floating stage and the widespread species are Ceratophyllum demersum, C. submersum, Myrophyllum spicatum and Polygonatum pectinatus.

\section{Marshy Stage}

The communities which constitute this stage of succession have grown comparativelly in shallow parts of Akgöl and Simenit lakes and in drainage canals where drawdowns occur in July, August and September, and thus turning it into temporarily terrestrial area. This major stage is divided into some intermediate stages according to the depth of water and the lenght of time when drawdowns occurs (Table 1). 
A community dominated by Nymphaea alba develop at a depth of $1.5-2 \mathrm{~m}$ in places close to the coasts of Akgöl and Simenit lakes and in drainage canals. This intermediate stage is the beginning stage of marshy major stage. While monodominant Typha angustifolia community develops in the parts of the lake and drainage canals, where the depth is $1 \mathrm{~m}$, in the parts where drawdown occurs in August monodominant Phragmites australis community develops.

In the parts of the lakes where drawdown occurs only in August and September monodominant Cladium mariscus community develops, while Sparganium erectum subsp. neglectum amphibic community develops in muddy habitats. Some of the species in the Cladium mariscus community are Hydrocotyle vulgaris, Rumex hydrolapathum and Salvinia natans and some of the species in the Sparganium erectum subsp. neglectum community are Apium graveolens, Alisma plantago-aquatica, Butomus umbellatus and Ludwigia palustris.

\section{Meadow Stage}

Juncus acutus community is widespread in the areas where there are hydromorphic and azonal soils, and where drawdown around Akgöl and Simenit lakes occur in July, August, September and October. In the areas where the water receding for longer periods of time, compared to marshy stage, the soil water table is high, and there are more herbaceous species among dense Juncus acutus tufts which adopted to inefficient oxygen (anoxia) and the pressure of grazing during the period when the water recedes. Widespread species in this community are Carex nigra subsp. nigra, Cynodon dactylon, Euphorbia hirsuta and Galium palustre.

\section{Flooded Forest Stage}

During the hydroseral progressive successional process in the sudy area, there is a direct transition from herbaceous stages to flooded forest stage. This stage develops into two substages. The first one is Alnus glutinosa subsp. barbata community and it grows in habitats flooded between December and April which extends as far as Akgöl and Simenit lakes. Some widespread species in this community are Physalis alkekengi, Ruscus aculeatus var. angustifolius, Rubus sanctus, Potentilla reptans and Carex vicaria.

Fraxinus angustifolia subsp. oxycarpa community which is the second substage of flooded forest stage appear in areas where flooding takes place rarely and in short period (December, January and February). Some widespread species in this community are Rubus canescens var. glabratus, Smilax excelsa, Oenanthe pimpinelloides and Poa trivialis.

\section{Climax Forest Stage}

Carpinus betulus forests which represent climax stage of hydroseral progressive succession appear in unflooded habitats of the study area. Compared to other communities representing different successional stages, the widespread species of these forests which have more species diversty are Carex remota, Brachypodium sylvaticum, Glechoma hederacea, Oplismenus undulatifolius, Hedera helix and Ruscus aculeatus var. angustifolius.

\section{Psammoseral Succession}

A psammoseral succession develops in sand dunes of the study area depending on how far it is from the sea. In these parts of the study area, since marine winds (sand drifting) wave flooding and physical and chemical changes in the structure of the sand dune by time functions as factors that effect the features of sand dune habitats, they lead to the development of successional process in the sand dune vegetation towards the land begining from the seaside. Psammoseral succession in this part of the study area consists of three major stages and four substages (Table 2, Figure 3).

\section{Unstable Dunes Stage}

It is a stage that develops in the parts of sand dunes which cover nearly 25 meters of an area into the land begining from the parts under direct influence of the sea water. In these parts of the sand dunes exposed to marine wind and waves the habitat is quite unstable because of the fact that sand grains are carried away by the above mentioned factors. In these parts of the sand dunes with an average altitude of $1 \mathrm{~m}$ a pioneer sand dune community dominated by Pancratium 
Table 2. Psammoseral successional stages.

\begin{tabular}{lc}
\hline Major Successional Stages & Intermediate Successional Stages and Communities \\
\hline 1-Unstable Dunes Stage & Pancratium maritimum community \\
\hline 2-Semistable Dunes Stage & a-Berberis vulgaris community \\
\cline { 2 - 2 } 3-Stable Dunes Stage & b-Vitex agnus-castus community \\
\hline
\end{tabular}

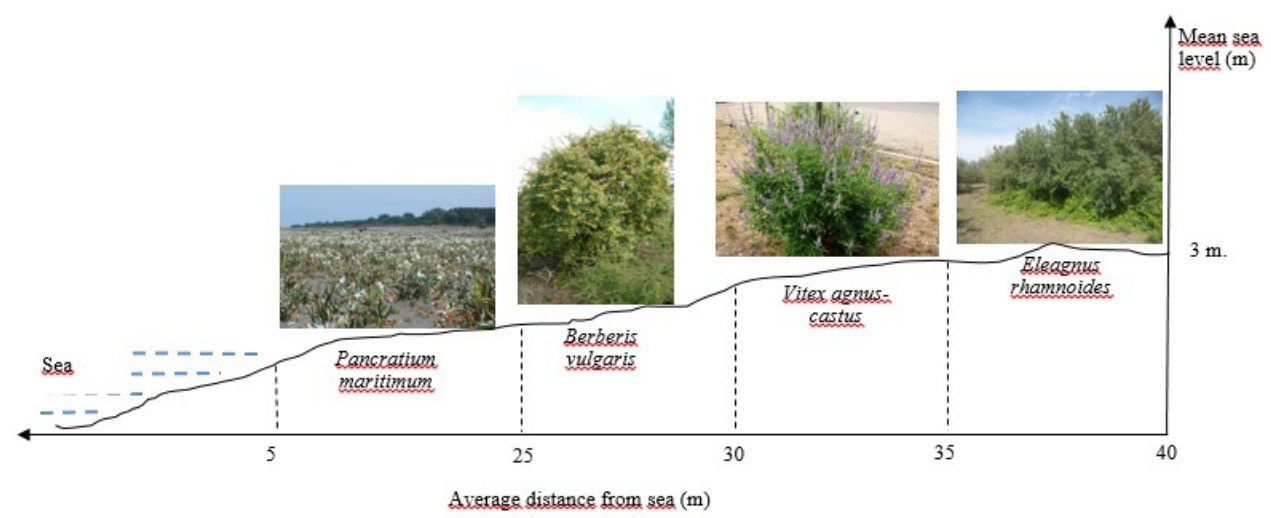

Figure 3. Stages of psammoseral succession.

maritimum has developed. Other common species in Pancratium maritimum community which can root in such habitats thanks to their bulbs deep in the sand are Eryngium maritimum, Cyperus capitatus and Cionura erecta which can root in the drifting sand dunes with their deep roots and rhizomes.

\section{Semistable Dunes Stage}

In the parts of the sand dunes almost 30 meters away from the sea, direct effect of the waves disappear completely and the effect of the wind lessens comparativelly. Due to the above mentioned factors, there is a relative reduction in the movements of sand, and thus embrionic sand dunes are formed. Communities dominated by Berberis vulgaris or Vitex agnus-castus made up of scrubby bushes with a height a of 1-1.5 m grow on the small sand dunes with a height of 1-2 $\mathrm{m}$. In general, while communities dominated by Berberis vulgaris grow on the small sand dunes closer to the sea, communities dominated Vitex agnus-castus grown on the small sand dunes which are comparativelly away from the sea. Bromus sterilis, Cionura erecta, Periploca graeca var. graeca, etc. are common on the sand dunes where Berberis vulgaris dominate the community, whereas Hordeum murinum subsp. glaucum, Rubus sanctus, etc. are common on the sand dunes where Vitex agnus-castus dominate the community.

\section{Stable Dunes Stage}

It is a stage that develop on the stable sand dunes, approximately $45 \mathrm{~m}$ away from the coast, which are about $3 \mathrm{~m}$ high. This stage is a climax stage of psammoseral succession and it is a scrub community dominated by Eleagnus rhamnoides subsp. caucasica. The common species in the vegetation are Rubus canescens var. glabratus, Hedera helix and Daucus carota.

\section{DISCUSSION}

According to our findings, in the study area, communities, which belong to the stages of hydroseral succession have developed based on the level of water in aquatic stage, and in the terrestrial and semi-terrestrial stages they have developed based on the period of during time which 
flooding and drawndown take place. Hovewer, while the habitats where aquatic communities grow are under water almost throughout the year at different depths, some of the habitats where semi-terrestrial and terrestrial communities grow are flooded at different lenghts of time, but the habitats where C6 community grows are never exposed to flooding. Edaphic differentation that appears in short distances are more effective than climatic factors on the distribution of the communities in delta plains. Besides, dynamics of flooding cause different successional stages to come out by creating different habitats such as marshy, river and semi-aquatic habitats [24]. The duration of flooding functions as a factor which has a direct effect on successional stages because it creates soil water table and soil moisture gradient.

As a result of this, while all the communities growing in standing water habitats are made up of aquatic and hygrophytic species, most of the communities in terrestrial flooding habitats are made up of mesophytic species. Especially aquatic communities in standing water areas are distributed according to their degree of tolerance to water level, flooding and saturation $[25,26]$. This situation can be observed best in the communities that belong to marshy stage. Likewise, the communities that belong to this stage are monodominant species that can root in the bottom mud at a depth of 1.5-2 m with their rhizomes, which can grow out of the water with their long stems and petiols, and which can adopted to marshy habitats thanks to their other anatomic (aeranchyma) and physiological (anoxia seed germination) properties.

The features of the soils in delta plains change based on the geological age of the stand [27-29], flooding regime [30-32] and physical and chemical properties of river or lake water. Local differences in the physical and chemical features of soil are influential on floristic composition, structure of the vegetation and distribution of the communities in the study area [33-36]. As the nutrients in soil are very important ecologically [37], local variation in the intake of these nutrients are the main factors that affect distribution of the species and arrangement of the communities in the area $[38,39]$. Most experimental studies suggest that the competition between the species is important in zonation of plants in marshy grounds [40].

Hydrologic zonation in terrestrial habitats function as an important indicator on the germination response of the species. Likewise, for the species belonging to early successional stage the content of the organic matter does not make any difference for germination, whereas the species that belong to late successional stage prefer soils with high organic matter content [41]. In addition, it has been determined that, since there is an interaction between soil moisture and soil temperature, water table level has an effected on the growth of root hair of woody species [42]. One of the most important charasteristics of early stage of psammoseral succession is that it is poor in terms of the nutrients of the habitat. The content of the nutrient in the habitat increases continually in later stages [43-45]. It is stated that, while the differences in the nitrogen mineralization process cause organic nitrogen in soil nutrient content have different forms, primary source of nitrogen that can be mineralized is soil biomass [46]. Besides, the amount of nitrogen available in sand dune habitats is one of the most important environmentalfactors, which has a dominant effect on species composition and primer productivity of plant communities [47]. Thus the changes in the features of the soil by time affect distribution of plant community, floristic composition and the structure of vegetation. Likewise, de Kovel et al. [29] stated that the amount of $C$ and $N$ increased in psammoseral successional process based on the age of vegetation. Collins and Wein [27] determined that early successional vegetation growing on sand dunes with different soil features had different structure and floristic composition. Elgersma [28] said that main factors that cause the formation of vegetation types in sand dunes are organic matter and available water. It was also stated that there was a relationship between the age of habitat and floristic composition and structure of vegetation and distribution of communities. Pennings and Moore [48] said that edaphic factors such as soil texture, the level of soil water table and redox level had a significiant role on the stratification of vegetation. Musila et 
al. [49] stated that, based on the geomorphologic age of sand dune, zonation of vegetation occured, and as a result of this, herbaceous vegetation grew in unstable sand dunes near the sea, and scrub vegetation grew on stable sand dunes.

\section{ACKNOWLEDGEMENTS}

This study was funded by the Research Council of Ondokuz Mayıs University (Project number: PYO.FEN.1904.11.025).

\section{References}

1. R. Knapp, Vegetation Dynamics, Science Press, Beijing, China, 1986.

2. A. Odland, R. del Moral, Thirteen years of wetland vegetation succession following a permanent drawdown, Myrkdalen Lake, Norway. Plant Ecology, 162 (2002) 185.

3. F.A. Bazzaz, The physiological ecology of plant succession, Ann. Rev. Ecol., 10 (1979) 351.

4. G.S. Zhang, R.Q. Wang, B.M. Song Plant community succession in modern Yellow River Delta, China, $\mathrm{J}$ of Zhejiang Univ. Sci. B, 8 (2007) 540.

5. M.K. Fierke, J.B. Kauffman, Riverscape- level patterns of riparian plant diversity along a successional gradient, Willamette river, Oregon. Plant Ecol., 185 (2006) 85.

6. P.C. Leendertse, A.J.M. Roozen, J. Rozema, Longterm changes (1953-1990) in the salt marsh vegetation at the Boschplaat on Terschelling in relation to sedimentation and flooding, Plant Ecology, 132 (1997) 49.

7. C.H. Kellogg, S.D. Bridghamt, Colonization during early succession of restored freshwater marshes. Can. J. Bot., 80 (2002) 176.

8. F. Berendse, E.J. Lammerts, H. Olff, Soil organic matter accumulation and its implications for nitrogen mineralization and plant species composition during succession in coastal dune slacks, Plant Ecology, 137 (1998) 71.

9. V. Hršak, Vegetation succession and soil gradients on inland sand dunes, Ecology Bratislava, 22 (2004) 24.

10. R. del Moral, L.L. Lacher, Vegetation patterns 25 years after the Eruption of Mount St. Helens, Washington, USA, American Journal of Botany, 92 (2005) 1948.

11. J. Dolezal, K. Homma, K. Takahashi, M.P. Vyatkina, V. Yakubov, V.P. Vetrova, T. Hara, Primary succession following deglaciation at Koryto Glacier Valley, Kamchatka. Arctic, Antarctic, and Alpine Research, 40 (2008) 309.

12. Anonim, Samsun il çevre durum raporu, Samsun Valiliği, Çevre II Müdürlüğü, Samsun, 2006.

13. E. Akkan, Bafra Burnu-Delice Kavşağı arasındaki Kızılırmak vadisinin jeomorfolojisi, Ank. Üniv. D.T.C.F., 191 (1970) 8.

14. T.Erkal, Yeşilırmak Deltası ve çevresinin jeomorfolojisi. Jeomorfoloji Dergisi, 20 (1993) 13.

15. Y. Akman, iklim ve Biyoiklim, Palme Yay. No:133 Ankara, 1990.
16. L. Emberger, Sur le Qoutien Pluviotermique, C.R. Acad. Sci., 234 (1952) 2508

17. S. Erinç, Yağış Müessiriyeti Üzerine Bir Deneme ve Yeni Bir İndis, iü Coğ. Enst. Yay. No: 41, İstanbul, 1965.

18. J. Braun-Blanquet, Pflanzensoziologie-Grundzüge der Vegetationskunde, Springer Verlag, Wien-New York, 1964.

19. V. Westhoff, E. van Der Maarel, The Braun-Blanquet aproach. In: Whittaker R.H. (ed.) Ordination and Classification of Communities, Dr. W. Junk bv Publishers, The Hague, pp., 617-626, 1973.

20. P.H. Davis (ed.), Flora of Turkey and the East Aegean Islands, Vols. 1-9, Edinburgh Univ. Press, Edinburgh, 1965-1985.

21. P.H. Davis, R.R Mill, K. Tan (eds.), Flora of Turkey and the East Aegean Islands, Vol. 10 (Suppl.), Edinburgh Univ. Press, Edinburgh, 1988.

22. A. Güner, N. Ozhatay, T. Ekim, K.C.H. Baser (eds.), Flora of Turkey and the Aegean Islands, Vol. 11 (suppl.), Edinburgh Univ. Press., Edinburgh, 2000.

23. A. Güner, S. Aslan, T. Ekim, M. Vural, M. T. Babaç (edlr.), Türkiye Bitkileri Listesi (Damarlı Bitkiler), Nezahat Gökyiğit Botanik Bahçesi ve Flora Araştırmaları Derneği Yayını, İstanbul, 2012.

24. J.W. Ward, K Tockner, F. Schiemer, Biodiversity of floodplain river ecosystems: ecotones and connectivity, Regulated rivers: research \& management, 15 (1999) 125.

25. A.G. van der Valk, Vegetation dynamics of freshwater wetlands: a selective review of the literatüre. Archiv für Hydrobiyologie,Beihang Ergebnisse der Limnologie, 27 (1987) 27.

26. E. Weiher, P. Keddy, The assembly of experimental wetland plant communities, Oikos, 73, (1995)323.

27. B. Collins, G Wein, Soil resourche hetereogeneity, Oikos, 82 (1998) 235

28. A.M. Elgersma, Primary forest succession on poor sandy soilsas related to site factors, Biodiversity \& Conservation, 7 (1998) 193.

29. C.G.F de Kovel., A.(J.)E.M. van Mierlo, Y.J.O Wilms., F. Berendse, Carbon and nitrogen in soil and vegetation at sites differing in succesional age, Plant Ecology, 149 (2000) 43.

30. G.T. Prance, G.B. Schaller, Preliminary study of some vegetation types of the pantanal, Mato Grosso, Brazil, Brittonia, 34 (1982) 228.

31. V.M. Ponce, C.N. da Cunha, Vegetated earthmounds in tropical savannas of central Brazil: a synthesis, Journal of Biogeography, 20 (1993) 219.

32. P. Zeilhofer, M. Schessl, Relationship between vegetation and environmental conditions in the northern Pantanal of Mato Grosso, Brazil, J. Biogeogr, 27 (1999) 159.

33. A.T. Oliveira-Filho, G.J. Shepherd, F.R. Martins, W. $H$. Stubblebine, Environmental factors affecting physiognomic and floristic variation in an area of cerrado in central Brasil, J. Trop. Ecol. 5 (1989) 413.

34. A.T. Oliveira-Filho,. Floodplain 'murundus' of Central Brazil: evidence for the termite-origin hypothesis, J. Trop. Ecol. 8 (1992) 1.

35. P. Zeilhofer, M. Schessl, Observations on inundation Dynamics and soil properties of selected vegetation types in the Pantanal of Pocone', II. SHIFT Workshop, Cuiaba', Brazil, 101, (1995). 
36. M. Kılınç, Bitki Sosyolojisi (Vejetasyon Bilimi), Palme Yayıncılık, Ankara, (2005).

37. F.J. Kruger, Plant community diversity and dynamics in relation to fire. In: Kruger F J, Mitchell DT, Jarvis JUM (eds.), Mediterranean-type Ecosystems, Ecological Studies 43, Springer, Berlin-Heidelberg, New York, pp., (1983) 446-472.

38. M.B. Richards, R.M. Cowling, W.D. Stock, Soil nutrient dynamics and community boundaries in the Fynbos vegetation of South Africa, Plant Ecology, 130 (1997) 143.

39. D Sabatier, M. Grimaldi, P. Marie-Françoise, G. Julie, G. Michel, D. Mireille, P. Curmi, The influence of soil cover organization on the floristic and structural heterogeneity of a Guinian rain forest, Plant Ecol., 131 (1997) 81.

40. S.D. Wilson, P.A. Keddy, Plant zonation on shoreline gradient: physiological response curves of component species, J. Ecol., 73 (1985) 851.

41. H.K. Chev, D.B. Scott, A.L. Stacey,. Effects of water level, shade and time on germination and growth of freshwater marsh plants along a simulated successional gradient, Journal of Ecology, 91 (2003) 274.

42. A. Montagnoli, A. di Iorio, M. Terzaghi, D. Trupiano, G. S. Scippa, D. Chiatante, Influence of soil temperature and water content on fine-root seasonal growth of European beech natural forest in Southern Alps, Italy, Eur. J. Forest Res. 133 (2014) 957.
43. R.L. Crocker, J. Major, Soil development in relation to vegetation and surface age at Glacier Bay, Alaska, Journal of Ecology, 43 (1955) 427.

44. J.S. Olson, Rates of succession and soil changes on southern Lake Michigan sand dunes, Botanical Gazette, 119 (1958) 125.

45. D. Tilman, Plant Strategy and the Dynamics and Structure of Plant Communities, Princeton University Press, Princeton, NJ (1988).

46. G. Stanford, S.J. Smith, Nitrogen mineralization potentials of soils, Soil Science Society of America Journal, 36 (1972) 465.

47. F. Berendse, Organic matter accumulation and nitrogen mineralizatıon during secondary succession in heathland ecosystems, Journal of Ecology, 78 (1990) 413

48. S.C. Pennings, D.J. Moore, Zonation of shrubs in western Atlantic salt marshes, Oecologia, 126 (2001) 587.

49. W.M. Musila, J.I. Kinyamario, P.D. Jungerius, Vegetation dynamics of coastal sand dunes near Malindi, Kenya, African Journal of Ecology, 39 (2001) 170. 
